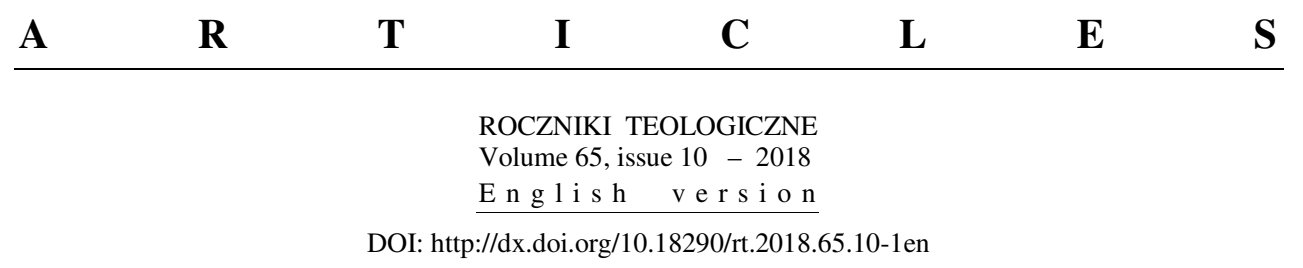

REV. MIROSŁAW BRZEZIŃSKI

\title{
FAMILY ECOLOGY AND ENVIRONMENTAL PROTECTION IN THE TEACHINGS OF THE CATHOLIC CHURCH
}

\begin{abstract}
Within a lifetime, man creates a natural family environment and must care to protect it. A manifestation of this ecological activity in the family is the ability to experience love, to learn respect and live together with other people. The quality of these community relationships and the lifestyle that people experience in the family shape pro-ecological attitudes. Cooperating with the Creator, man cares for the protection of human life. Therefore, he undertakes actions aimed at eliminating degrading and destructive processes, and strives to live in harmony with the natural environment. In fact, man is an inseparable element of the environment, and therefore caring for his survival is most essential. Man is also called to rule the earth through work and development, while at the same time becoming spiritually mature and more responsible, especially towards the weak and needy.
\end{abstract}

Keywords: family; environment; family ecology; environmental ecology.

The family is the natural environment in the life of every person. Here, in an atmosphere of love, man is brought to life, is born, develops and shapes himself and his personality, maturing and eventually dying. This environment, in which he experiences love, is where a person learns to be loved and loves others, coexisting with other people who care for this family environment. The family is the sanctuary of life, the center of care for life and the culture of life; it is the first and basic cell of human ecology. ${ }^{1}$

Man is the greatest treasure for the family. ${ }^{2}$ Such an understanding of the family leads to our reflection, since it is family ecology that helps us to un-

Rev. Dr. Hab. MirosŁaw BrzeziŃSKI is an adjunct at the Department of Palliative and Hospice Social Care at the Institute of Family Studies and Social Work at KUL; mailing address: Al. Racławickie 14, 20-950 Lublin, e-mail: mbrzezinski@kul.pl

${ }^{1}$ Cf. John PAUl II, Encyclical Centesimus annus (May 1, 1991), no 39.

${ }^{2}$ Ibidem, no 32. 
derstand and care for the basic and natural environment for man's integral development. Activities undertaken on behalf of the family are an expression of our care for man and acquire ecological significance, since it is man's natural life environment. Protecting and caring for this natural environment supporting life and man's development is an expression of love for the family. To love the family is to be able to see its value and possibilities, to always support it, to perceive the dangers and evil that threaten it in order to be able to overcome it, to contribute to creating an environment that supports its development, to regain trust in itself, its own natural richness and grace, and the mission given it by God. ${ }^{3}$

After the fall, God placed man in the garden of Eden, so that he may develop, grow and live in harmony with nature. Apart from the family, the natural environment is the second place for man to live and develop. Family ecology is both protecting a family from all dangers, but family ecology is also concerned with protecting the natural environment. This means undertaking all steps that have as their goal protecting the natural environment as the environment of man's life and development. ${ }^{4}$ The need to care for the family and nature, the environment in which man lives and develops, is the task given to individuals, entire families, and all of society. This care is an expression of our attitude towards nature, it is a question of ecology, meaning accepting certain human undertakings as positive for the environment in which man lives and develops, while other things are negative. ${ }^{5}$

Taking into consideration the above, we want to show the mutual dependence between the family environment and ecological activities in the family. The family is the natural environment that integrates man's development with ecological activities related to protecting the natural world. Man was placed in the world by the Creator, who gave him the command to "fill the earth and subdue it" (Gen 1,28). We want to show that protecting the family as the basic cell of human ecology has a direct influence on protecting the natural environment, the world of nature, and we want to do this based on the current teachings of the Church.

\footnotetext{
${ }^{3}$ Cf. John PAUl II, Apostolic Exhortation Familiaris consortio (22.11.1981), no 86.

${ }^{4}$ Cf. Ochrona środowiska, in http://www.ekologia.pl/wiedza/slowniki/ leksykon-ekologii-iochrony-srodowiska/ochrona-srodowiska (April 30, 2018).

${ }^{5}$ Cf. Andrzej PApuziński, "Historyczne a współczesne motywy i cele ochrony przyrody," in Rozmaitości ekofilozofii, ed. Antoni Skowroński (Olecko: Wydawnictwo Wszechnicy Mazurskiej Acta Universitatis Masuriensis, 2006), 36-37.
} 


\section{MAN IS IN COMMUNITY WITH THE NATURAL ENVIRONMENT}

The description of the creation of the world and mankind in the Book of Genesis (cf. Gen 1:1-2,25) gives man an exceptional place in the world. God invites man to co-create the world by naming everything that was created, to independently cultivate the environment and develop it. God does not impose his way of understanding the world on man, nor does God create the world and man's way of being in this world, but gives us laws as to how to do it (cf. Gen 2:15-20). ${ }^{6}$

When we see the role that man has been given in the work of creation, one can say that he is not only part of the entire created world, but that he must develop the world wisely and take care of it in the sense of being in fellowship with nature. When satisfying his needs, man should follow a lifestyle that allows him to actively participate in the environment surrounding him. ${ }^{7}$ Man is responsible for how he shapes the world, and at the same time is responsible for his own personality and for how he develops himself. ${ }^{8}$

As in the natural world, which man is a part of, all creatures are inter-related and need each other, and each of them must be appreciated with love and admiration. The man to whom God commissioned "dominion over all creation" (Gen 1:28) is responsible for protecting our world. "How a person treats the natural environment influences how he treats himself and vice versa. This is a call for today's society to seriously check our lifestyle."10

Our human lifestyle must consist of taking on the attitude of metanoia, which means a complete change of mentality within our individual, social and political consciousness, making it possible to protect the environment of life and build a civilization of life. ${ }^{11}$ Benedict XVI points to the need to adopt this new lifestyle, in which the search for truth, beauty and goodness in building the human community are visible. Benedict XVI stresses that violating solidarity and interpersonal friendliness causes ecological damage,

\footnotetext{
${ }^{6}$ Cf. Krystyna NAJDER-STEFANIAK, "Twórcze działanie w paradygmacie ekologicznym," in Rozmaitości ekofilozofii, ed. Antoni Skowroński (Olecko: Wydawnictwo Wszechnicy Mazurskiej Acta Universitatis Masuriensis, 2006), 217.

${ }^{7}$ Cf. Stefan KonstańCZAK, "Kontrowersje wokół ekologii głębokiej.” In Rozmaitości ekofilozofii, 129.

${ }^{8}$ NAJDER-STEFAniak, “Twórcze działanie w paradygmacie ekologicznym,” 218.

${ }^{9}$ Cf. Francis, Encyclical Laudato si (24.05.2015), no 42.

${ }^{10}$ Benedict XVI, Encyclical Caritas in veritate (29.07.2009), no 51.

${ }^{11}$ Cf. Józef M. DoŁĘGA, “Ekofilozofia i jej otulina.” In Rozmaitości ekofilozofii, 64-65.
} 
just as the degradation of the environment causes dissatisfaction in social relationships. $^{12}$

Thus, all ecological initiatives should first of all protect man from destroying himself. Degrading the natural world is closely related to the culture that shapes attitudes towards life. If people respect life, the natural environment also benefits. If the right to life and a natural death are not respected, if we perform artificial conceptions to get pregnant and give birth to human beings, and this includes sacrificing human embryos for research purposes, then in the general awareness, in the end, the idea of human ecology is lost, and along with it goes our concept of environmental ecology. An attitude of respect and protection of the natural environment will be possible if the young generation is brought up in an attitude of respect towards themselves. Nature's book is indivisible when it concerns the environment and the areas of life, sexuality, marriage, family, social relations, and generally speaking, integral human development. Obligations that we have in relation to the environment are connected with the obligations that we have towards people and in relationships with others. ${ }^{13}$

Therefore, if "man is a creature who has the right to life and happiness in this world, and he is also granted special dignity, then we cannot fail to take into account the effects of environmental degradation, current development trends and a culture that rejects human life."14 After all, defending life and strengthening it, honoring and loving it is a task which God entrusts to every man. God calls man to participate in his divine dominion over the world. This is about lordship over the land and every living being. Man is called to cultivate the garden, which is the entire world, and guard it (cf. Gen 2:15). Therefore, man in a special way is responsible for a created reality that through God's will was given to him.

This responsibility is expressed in respecting and protecting the great good that is present in every life. In fact, the domination that the Creator handed over to man does not mean absolute power or the arbitrariness of "using" and disposing of things. The limitations imposed on man by the Creator himself and expressed symbolically in the prohibition "do not eat the fruit of the tree" (cf. Gen 2:16-17) clearly shows that in relation to the visible natural world, man is subject not only to biological laws, but also to

\footnotetext{
${ }^{12}$ Cf. Benedict XVI, Encyclical Caritas in veritate, no 51.

${ }^{13} \mathrm{Cf}$. ibidem.

${ }^{14}$ Francis, Encyclical Laudato si, no 43.
} 
moral laws, which he cannot trespass,${ }^{15}$ that he should live in symbiosis with nature and that he is responsible for it. The Church's teaching stresses that nature's book is undivided when it comes to the environment, life, sexuality, family, and social relationships. Environmental protection or degrading it are closely related with man's attitude towards life. The family and the natural environment are deeply wounded because of man's irresponsible behavior that flows from the conviction that irrefutable truths do not exist, those that dictate human life, because some erroneously state that man is totally free in his actions. He forgets that his freedom is not what he himself creates. If man gives himself the last word, if everything were to depend on man's will, then life would be threatened. ${ }^{16}$

Man is to exercise authority over nature in a responsible way in order to benefit from the natural world. At the same time, he should care for it and above all be careful so that nature will honorably accept and nourish the population living on earth. This means that it is necessary to make decisions that aim to strengthen the covenant between man and the environment that reflect the creative love of God, from whom man comes and to whom he is going. ${ }^{17}$

\section{THE FAMILY. THE PLACE TO FORM PRO-ECOLOGICAL ATTITUDES}

John Paul II taught that the family is the first and basic cell of "human ecology" in which man receives the first and decisive ideas related to truth and goodness. It is where he first learns what it means to love and be loved, what it means to be a person. This is a family based on marriage, where the mutual gifts of a man and a woman create a living environment in which a child can be born and develop. In a family, a child can develop its abilities, becomes aware of its dignity and prepares to take on its unique and unrepeatable destiny. The Pope pointed to the necessity of discovering once again that the family is a sanctuary of life; it is the place in which life, a gift from God, can be properly accepted and protected from the numerous attacks to which it is exposed.

Here, we learn that man himself is a gift received from God and therefore he must respect the natural and moral structures with which he has been

\footnotetext{
${ }^{15}$ JoHn PAUL II, Encyclical Evangelium vitae (25.03.1995), no 42.

${ }^{16}$ Cf. FrancisZer, Encyclical Laudato si, no 6.

${ }^{17} \mathrm{Cf}$. Benedict XVI, Encyclical Caritas in veritate, no 50.
} 
equipped. ${ }^{18}$ Protecting the family as a sanctuary of life also includes questioning the so-called demographic issue and "reproductive policy." Benedict XVI indicates that today, one of the most obvious aspects of human development is respect for life and accepting every life, especially where it encounters various obstacles. He draws attention to the practices of demographic population control used in various parts of the world, meaning contraception or abortion, as well as anti-life legislation, which create customs and practices that result in an antenatal mentality.

Negating and destroying life leads to a situation in which society does not find the motivation and energy needed to serve what is truly good for man. In the meantime, being open to the life and accepting it are the center of real development, these strengthen moral forces and enable us to mutually help each other. When adopting an attitude of openness to life, noble actions are supported by a morally healthy lifestyle and development in solidarity that respects the fundamental rights of every person to be given life. ${ }^{19}$ Therefore, all forms of pressure on people in matters concerning accepting life and caring for it according to John Paul II are a new form of violence that leads to the destruction of the lives of millions of helpless human beings. These practices do not serve development and cannot be considered as elements of development. $^{20}$

Also, Pope Francis points to the disturbing fact of people defending the integrity of the natural environment and limiting scientific research by some ecological movements on the one hand, while at the same time the lack of such protective activities and applying the same principles to the human life. He draws attention to the fact that experiments on living human embryos are being performed, often justified and trespassing all dignified limits, forgetting that the inalienable value of a human being far surpasses the level of mankind's development. ${ }^{21} \mathrm{He}$ also indicates that caring for life and demographic growth can be fully reconciled with integral and solidary social and economic development. ${ }^{22}$

The cognition that takes place in the family also includes getting to know the world of nature, the laws that govern in it and learning how to respect the

\footnotetext{
${ }^{18}$ Cf. John Paul II, Encyclical Centesimus annus, no 38-39; Anna Latawiec, "Rodzina ekologiczna - co to jest?” in Ekologia rodziny ludzkiej, ed. Józef M. Dołęga, Jacek W. Czartoszewski (Olecko: Wydawnictwo Wszechnicy Mazurskiej Acta Universitatis Masuriensis, 2000), 51.

${ }^{19}$ BenEDICT XVI, Encyclical Caritas in veritate, no 28.

${ }^{20}$ Cf. John Paul II, Encyclical Centesimus annus, no 39.

${ }^{21}$ Cf. Francis, Encyclical Laudato si, no 136.

${ }^{22}$ Ibidem, no 50.
} 
natural environment in which man lives. As A. Latawiec emphasizes, "getting to know and experiencing nature is a prerequisite for being able to understand it. This is about shaping the ecological awareness of every human being at every stage of life. This process should include, inter alia, such facts as: man's influence on the state of the environment, the area of his external environment, responsibility for the state of the biological environment, and the influence of the state of the environment on health. Our knowledge shapes ecological awareness." 23

He goes on to say that the family that maintains harmony between the "inner" and "external" life environment, meaning between the people forming the family community, their social life and natural environment, create an ecological family that shapes responsible people who live in truth and love. These family members are just, respecting life and the rights and obligations resulting from the gender roles assigned to them. In such a family, thanks to proper communication, there is full harmony between the internal environment of each "I" and the "we" environment (the entire family), and the external "them" environment (society and nature). ${ }^{24}$ Moral duties are a result of these dependencies, and they are needed for the human being, family, society and humanity to protect the environment. This emerges from the knowledge of this mutual dependence, and directly stems from the fact that man is a part of the natural environment. When he takes care of himself, at the same time, he also cares for the environment of life. ${ }^{25}$

Lack of concern for the natural environment leads to a drastic reduction in the quality of living conditions for man and his family. A family is an indispensable place for shaping pro-ecological attitudes, educating us to respect nature and its rights, meaning to use, in a responsible way, the goods God gives to man. ${ }^{26}$ It is worth noting that "the possibilities of pro-ecological family education rely on the fact that the family raises their offspring from the very beginning by shaping one's consciousness. This has a decisive influence on a person's behavior towards nature which is shaped over a long time." ${ }^{27}$ It seems obvious that when the family appreciates the importance of the natural environment, protects it and strives to strengthen it, we increase

\footnotetext{
${ }^{23}$ LatAwiEC, "Rodzina ekologiczna - co to jest?" 56.

${ }^{24}$ Cf. ibidem, 56-57.

${ }^{25}$ Cf. KonstańCZAK, "Kontrowersje wokół ekologii głębokiej,” 125.

${ }^{26}$ Cf. DoŁĘGA, "Ekofilozofia i jej otulina," 65.

${ }^{27}$ WORONOWSKI, “Zagadnienie proekologicznego wychowania w rodzinie," 234.
} 
our pro-ecologic impact on a child, and through education, a family forms pro-ecological attitudes which we really need today. ${ }^{28}$

\section{QUALITY OF LIFE AND METHODS OF ENVIRONMENTAL PROTECTION}

A great challenge for man and for today's families in the context of protecting the environment is the increasingly popular consumerist culture and the "culture of the ephemeral," 29 as Pope Francis described. When needs arise and we must determine what they are, they are always dependent on the more or less correct concept of man and his real good. A specific culture emerges from decisions regarding production and consumption and their general concept of life. It is here that the phenomenon of consumerism is created, ${ }^{30}$ that is, excessive attachment to acquiring material goods. ${ }^{31}$ However, John Paul II teaches that in determining man's needs and ways to satisfy them, it is necessary to follow man's integral vision as someone who embraces all dimensions of existence, subordinating the material dimension to the spiritual dimension.

Equally worrying is the ecological question which accompanies the problem of consumerism and which is closely connected to it. In his desire to have and to enjoy rather than to be and to grow, man consumes the resources of the earth and his own life in an excessive and disordered way. At the root of the senseless destruction of the natural environment lies an anthropological error, which unfortunately is widespread in our day. Man, who discovers his capacity to transform and in a certain sense create the world through his own work, forgets that this is always based on God's prior and original gift of the things that are. Man thinks that he can make arbitrary use of the earth, subjecting it without restraint to his will, as though it did not have its own requisites and a prior God-given purpose, which man can indeed develop but must not betray. Instead of carrying out his role as a co-operator with God in the work of creation, man sets himself up in place of God and thus ends up provoking a rebellion on the part of nature, which is more tyrannized than governed by him. ${ }^{32}$

\footnotetext{
${ }^{28}$ Cf. ibidem, 236-237.

${ }^{29}$ FrANCIS, Encyclical Amoris laetitia, no 39.

${ }^{30}$ Cf. John PaUl II, Encyclical Centesimus annus, no 36.

31 "Konsumizm [Consumerism]," in: https://sjp.pwn.pl/sjp/;2473455 (14.02.2018).

${ }^{32}$ John Paul II, Encyclical Centesimus annus, no 37; cf. WoronowsKi, "Zagadnienie proekologicznego wychowania w rodzinie," 229-230.
} 
Therefore, when a person comes closer to nature and the environment, he must be open to experiencing wonder, he must speak in a language of brotherhood and beauty in relation to the world. He cannot assume the attitude of a ruler and a consumer who uses natural resources, unable to set limits to his everyday interests. He must feel connected to nature and use its goods in moderation, ${ }^{33}$ with a sense of care for the environment and his life, showing responsibility to future generations and the Creator who gave him the land to subdue, but not in mindless consumption.

Concerning this consumerist culture, Francis also mentions the so-called ephemeral culture, which manifests itself in the speed with which people pass from one emotional relationship to another, and in the fear aroused by the prospect of constantly being involved, an obsession with free time in relationships that always calculates costs and benefits. These emotional relationships reflect what happens with objects and the environment: everything can be thrown away, everyone uses and throws away, wastes, destroys, or abuses, as long something serves them. When something or someone does not serve me, I get bored, so I throw it away. ${ }^{34}$ If man does not respect the gifts of nature, he must realize that it will turn against man.

Pope Francis also points out that the process of degrading the human and the natural environment does not occur simultaneously and that man will not be able to cope with the degradation of the natural environment, unless he now starts to pay attention to the causes related to such degradation. ${ }^{35}$ The ecological crisis is, according to Francis, an outward manifestation of man's ethical, cultural and spiritual crisis. It is difficult to think about healing man's relationship with nature and the natural environment without first healing basic interpersonal relationships. ${ }^{36}$ Because family and nature are the natural environments for human life, we are not talking about two separate crises, one environmental and the other social, but about one complex social and ecological crisis. ${ }^{37}$ Overcoming mankind's crisis and the crisis of the family in the modern world means opening a way to overcome the ecological crisis and protect the environment of human and family life.

\footnotetext{
${ }^{33}$ Cf. Francis, Encyclical Laudato si, no 11.

${ }^{34}$ Cf. FrancIs, Encyclical Amoris laetitia (19.03.2016), no 39.

${ }^{35}$ Cf. Francis, Encyclical Laudato si, no 48.

${ }^{36} \mathrm{Cf}$. ibidem, no 119.

${ }^{37}$ Ibidem, no 139.
} 


\section{THE CHALLENGE}

Seeing a relationship between human life, family life and the protection of the environment, it is worth paying attention to the challenges that today's world brings to mankind, including his own connection with the quality of life, the life of the family and the life of the natural environment. From the above cited teachings of the Church, two aspects are seen as the basic human activities for the protection of one's basic living environment. The first concerns man and the family itself as a sanctuary of life in which one learns to respect every human life, to shape life attitudes and to protect life. This means moral responsibility for life from its very conception; it means being aware that human life is a gift from God, it has inalienable dignity, and that only God is the Lord of life, and this gift has been put into man's hands to be developed.

The second challenge and task is related to our attitude towards the natural environment, our development and work. Today's man, as John Paul II pointed out, seems to be constantly threatened by his own creations, the things he has built by hand, the works of his mind, and his will. The fruits of this manifold activity, if they are not ordered and in accord with the Creator's plan, may be directed against man, and this is usually unforeseen and unpredictable. This seems to be the main element of the drama of modern man, who seems to be living in fear. This is a fear that his creations can be radically turned against him, so that they can become the means and tools of some unimaginable self-annihilation. ${ }^{38}$

In order to get rid of this fear, a person must use the authority that was given to him at the time of creation, the power he has to subdue the earth (cf. Gen 1:28) in such a way that the use of natural resources and all his actions do not threaten him. It seems that at present, man is more aware that the use of the land he lives on demands rational and honest planning, and that the goods of the natural environment do not simply serve the purpose of immediate use and consumption. It is the Creator's intention that man should associate with nature as its rational and noble "master" and "guardian" and not as an absolute "exploiter."

Development means that people must apply morality and ethics. It demands that man, through his work and development, become more and more like his Creator (cf. Gen 1:27), to become better, more spiritually mature,

\footnotetext{
${ }^{38}$ JoHn PAUL II, Encyclical Redemptor hominis (4.03.1979), no 15.
} 
more aware of the dignity of his humanity and more responsible. ${ }^{39}$ Man's real development is moral in nature, involving full respect for the human person. It is also directed towards the world of nature and must take into account the nature of every being and their mutual connection to the ordered system. For this reason, man's ability to transform reality should be developed on the basis of the original purpose of created things as designated by God. ${ }^{40}$ Man's attitude towards himself and the natural environment is therefore the key to human development and the development of life on earth. ${ }^{41}$ This can only be achieved through the moral renewal of humanity and family life.

\section{BIBLIOGRAPHY}

BENEDICT XVI. Encyclical Caritas in veritate (29.07.2009).

DołęGA, Józef M. "Ekofilozofia i jej otulina.” In Rozmaitości ekofilozofii, [Eco-Philosophy and its Buffer Zone, in: The Diviersity of Eco-philosophy], edited by Antoni Skowroński, 43-67. Olecko: Wydawnictwo Wszechnicy Mazurskiej Acta Universitatis Masuriensis, 2006.

FRANCIS. Encyclical Laudato si (June 24, 2015).

Francis. Encyclical Amoris laetitia (March 19, 2016).

John PAUL II. Encyclical Redemptor hominis (March 4, 1979).

JOHN PAUL II. Encyclical Laborem exercens (September 14, 1981).

JoHn PAUl II. Encyclical Familiaris consortio (November 22, 1981).

John PAUL II. Encyclical Centesimus annus (May 1, 1991).

John PAUL II. Letter to Families (February 2, 1994).

JoHn PAUL II. Encyclical Evangelium vitae (March 25, 1995).

KonstańcZaK, Stefan. "Kontrowersje wokół ekologii głębokiej.” In Rozmaitości ekofilozofii, [Controversies Over Deep Ecology, in: The Diviersity of Eco-Philosophy], edited by Antoni Skowroński, 121-140. Olecko: Wydawnictwo Wszechnicy Mazurskiej Acta Universitatis Masuriensis, 2006.

“Konsumizm”[Consumerism]. In https://sjp.pwn.pl/sjp/;2473455 (14.02.2018).

LATAWIEC, Anna. "Rodzina ekologiczna_co to jest?” In Ekologia rodziny ludzkiej [What Is the Ecological Family? in: Ecology of the Human Family], edited by Józef M. Dołęga, Jacek W. Czartoszewski, 43-57. Olecko: Wydawnictwo Wszechnicy Mazurskiej Acta Universitatis Masuriensis, 2000.

NAJDER-STEFANIAK, Krystyna. “Twórcze działanie w paradygmacie ekologicznym.” In Rozmaitości ekofilozofii [Creative Action in the Ecological Paradigm, in: The Diviersity of Eco-Philosophy], edited by Antoni Skowroński, 201-220. Olecko: Wydawnictwo Wszechnicy Mazurskiej Acta Universitatis Masuriensis, 2006.

\footnotetext{
${ }^{39}$ Ibidem.

${ }^{40}$ FrANCIS, Encyclical Laudato si, no 5.

${ }^{41}$ Cf. Woronowski, “Zagadnienie proekologicznego wychowania w rodzinie,” 231.
} 
"Ochrona środowiska" [Environmental Protection], in http://www.ekologia.pl/wiedza/slowniki/ leksykon-ekologii-i-ochrony-srodowiska/ochrona-srodowiska (30.04.2018).

PAPUZIŃSKI, Andrzej. "Historyczne a współczesne motywy i cele ochrony przyrody." In Rozmaitości ekofilozofii [Historical and contemporary motifs and goals of nature conservation, in: The variety of ecophilosophy], edited by Antoni Skowroński, 29-41. Olecko: Wydawnictwo Wszechnicy Mazurskiej Acta Universitatis Masuriensis, 2006.

PAul VI. Encyclical Populorum progressio (March 26, 1967).

WORONOWSKI, Franciszek. “Zagadnienie proekologicznego wychowania w rodzinie.” In Ekologia rodziny ludzkiej [The Problem of Pro-Environmental Education in the Family, in: Ecology of the Human Family], edited by Józef M. Dołęga, Jacek W. Czartoszewski, 229-244. Olecko: Wydawnictwo Wszechnicy Mazurskiej Acta Universitatis Masuriensis, 2000.

Translated by Jan Kobytecki

The preparation of the English version of Roczniki Teologiczne (Annals of Theology) and its publication in electronic databases was financed under contract no. 836/P-DUN/2018 from the resources of the Minister of Science and Higher Education for the popularization of science. 